\title{
PHYSICAL EXERCISE IN THE PROMOTION OF GENE THERAPY AUXILIARY EFFECT
}

\section{O EXERCÍCIO FÍSICO NA PROMOÇÃO DE EFEITOS AUXILIARES DA TERAPIA GENÉTICA}

\section{EL EJERCICIO FÍSICO EN LA PROMOCIÓN DE EFECTOS AUXILIARES DE LA TERAPIA GENÉTICA}

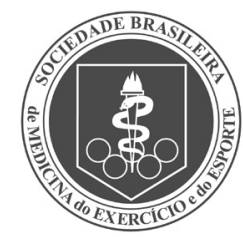

Original Article

ARTIGo ORIGINAL

Artículo Original

\begin{abstract}
Wei Shen ${ }^{1}$ (D)
(Physical Education Professional)

Xiaojun Liang 2,3 (iD)

(Physical Education Professional)

1. College of Physical Education, Hubei Normal University, Huangshi, Hubei, China.

2. Public Foundation Department,

Zhaoqing Medical College,

Zhaoqing, Guangdong, China.

3. Graduate School, University of

Perpetual Help System DALTA, Las

Piñas City, Manila, Philippines.
\end{abstract}

\section{Correspondence}

Xiaojun Liang

Las Piñas City, Manila, Philippines,

1740. liangxiaojun@zqmc.edu.cn

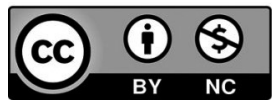

\begin{abstract}
Introduction: In recent years, genetic engineering has made outstanding contributions to sports, and it has played a huge role in promoting the development of sports-related fields. Objective: We analyze the tissue source of bone growth and healing by studying the role of bone morphogenetic protein and transforming growth factors in fracture injuries caused by sports. Methods: We established a human fracture model to express the shape and content of bone morphogenetic protein and transforming growth factor during fracture healing. Results: In the fracture healing stage caused by different sports, the expression levels of the two genes are different. Bone morphogenetic protein has a high content in the osteogenesis stage of the membrane, while transforming growth factor is high in the cartilage ossification stage. Conclusion: Gene therapy for fractures caused by physical exercise has certain advantages. Osteoblasts and chondrocytes are involved in the synthesis of transforming growth factors. Level of evidence Il; Therapeutic studies - investigation of treatment results.
\end{abstract}

Keywords: Sports; Bone Morphogenetic Protein 1; Gene therapy.

\section{RESUMO}

Introdução: Nos últimos anos, a engenharia genética tem contribuído de forma notável para os esportes, além de ter uma função importante na promoção do desenvolvimento de áreas relacionadas ao esporte. Objetivo: Analisamos a origem de tecidos do crescimento ósseo e sua regeneração através do estudo da proteína morfogenética óssea e fatores de transformação do crescimento em fraturas causadas pela prática do esporte. Métodos: Criamos um modelo de fratura humana para expressar a forma e o conteúdo da proteína morfogenética óssea e de fatores de transformação do crescimento durante a recuperação de fraturas. Resultados: Na fase de recuperação da fratura causada por diversos esportes, os niveis de expressão dos dois genes são diferentes. A proteína morfogenética óssea se apresenta em alta quantidade na fase osteogenetica da membrana, e o fator de transformação de crescimento apresenta alta quantidade na fase de ossificação da cartilagem. Conclusão: A terapia genética para fraturas causadas por exercícios físicos apresenta diversas vantagens. Osteoblastos e condrócitos tem um papel na síntese dos fatores de transformação do crescimento. Nível de evidência ll; Estudos terapêuticos - investigação de resultados de tratamento.

Descritores: Esportes; Proteína morfogenética óssea 1; terapia genética.

\section{RESUMEN}

Introducción: En los últimos años, la ingeniería genética ha contribuido de forma notable para los deportes, además de tener una función importante en la promoción del desarrollo de áreas relacionadas al deporte. Objetivo: Analizamos el origen de tejidos del crecimiento óseo y su regeneración a través del estudio de la proteína morfogenética ósea y factores de crecimiento transformante en fracturas causadas por la práctica del deporte. Métodos: Creamos un modelo de fractura humana para expresar la forma y el contenido de la proteína morfogenética ósea y de factores de crecimiento transformante durante la recuperación de fracturas. Resultados: En la fase de recuperación de la fractura causada por diversos deportes, los niveles de expresión de los dos genes son diferentes. La proteína morfogenética ósea se presenta en alta cantidad en la fase osteogénica de la membrana, y el factor de crecimiento transformante presenta alta cantidad en la fase de osificación del cartílago. Conclusión: La terapia genética para fracturas causadas por ejercicios físicos presenta diversas ventajas. Osteoblastos y condrocitos tienen un papel en la síntesis de los factores de crecimiento transformante. Nivel de evidencia ll; Estudios terapéuticos - investigación de resultados de tratamiento.

Descriptores: Deportes; Proteína Morfogenética Ósea 1; Terapia Genética. 


\section{INTRODUCTION}

Fracture repair until healing is a complex tissue change process, which involves a series of different cell activities. These include cell proliferation, differentiation, and extracellular matrix synthesis. The fracture healing model is a good model for studying bone induction, bone growth and bone repair.' After the fracture, the repair process starts immediately and is regulated by systemic and local factors. Among them, local regulation and inducing factors play an important role in the chemotaxis, aggregation, proliferation and differentiation of cells. Among the numerous growth factors, bone morphogenetic protein (BMP) and transforming growth factor $\beta$ (TGF $\beta$ ) have attracted more and more attention. In the process of bone repair, BMP and TGF $\beta$ can play a role alone, or they can work together. So far, little is known about the synergy between them. Because BMP2 and TGF $\beta 1$ are closely related to bone tissue.2 For this reason, the author established a model of jaw fracture and used in situ hybridization to detect the expression of BMP2 and TGF $\beta 1$ mRNA at different stages of fracture healing. In this way, we further explore the tissue cell source, mode of action and the relationship between the two in the bone growth and healing of BMP and TGF $\beta$, and at the same time we explore the mechanism of bone growth and healing.

\section{METHOD}

Probe

The PSP65-BMP2 plasmid was provided by Dr. Wozney of the American Institute of Genetics. Obtained by alkaline lysis method, phenol/ chloroform extraction, FPLC-Q column purification and ethanol precipitation method. ${ }^{3}$ The hTGF $\beta 1$ oligonucleotide probe was purchased from Oncogene Science, USA.

\section{The labeling of the probe}

We use random primer extension method to incorporate DIG-labeled dUTP into the BMP2 probe with reference to the DIG Labeling and detection kit. We used the 3'end labeling method to incorporate DIG-labeled dUTP into the 3 end of the hTGF $\beta 1$ oligonucleotide.

\section{Establishment of fracture model and specimen processing}

24 healthy adult male rabbits $(1.6 \sim 2.2 \mathrm{~kg})$. Under $3 \%$ sodium pentobarbital $(1 \mathrm{ml} / \mathrm{kg})$ general anesthesia, he used a dental turbine to cause a complete fracture at the anterior notch of the unilateral mandibular angle. ${ }^{4}$ We use steel wire ligation to fix and suture the periosteum, muscle and skin layer by layer. We collected materials on the 1, 3, 5, 7, 11, 14, 21 , and 28 days after surgery ( 3 rabbits at each time point). Before the experiment, the material was perfused and fixed with $4 \%$ paraformaldehyde solution, and then the bone stump and surrounding tissues were taken and fixed for 4 hours $\left(4^{\circ} \mathrm{C}\right)$. After routine decalcification, the sections are $5 \mu \mathrm{m}$ thick after paraffin embedding. The entire process is strictly prevented from RNAase contamination.

\section{In situ hybridization}

After the sections were fully deparaffinized, we put them in DEPC water and $0.1 \mathrm{~mol} / \mathrm{LPBS}(\mathrm{pH} 7.4), 0.2 \mathrm{~mol} / \mathrm{L}$ hydrochloric acid and soaked for 20 minutes. Then we digested with proteinase K (PK) for 15 minutes and stopped the reaction with $0.2 \%$ glycine. After fixation in $4 \%$ paraformaldehyde/PBS for 30 minutes, the hybridization was performed at $42^{\circ} \mathrm{C}$ for 20 hours after dehydration with gradient alcohol. The BMP2 probe was heat-denatured in a boiling water bath for 5 minutes before hybridization. After hybridization, we used $2 \times$ SSC, $1 \times$ SSC, and $0.5 \times$ SSC to rinse thoroughly. At the same time, the test uses Anti-DIG-AP (1:500) for detection, and NBT/BCIP color development. ${ }^{5}$ The control is set as a positive control (osteosarcoma), a blank control where we omit the probe, and a RNAase digestion control.

\section{Fracture image recognition method}

It is assumed that all image gray values of the fracture image frame satisfy the expected value of image gray value $\mu$. The variance of the image gray value distribution is the normal distribution of $\sigma$. And it satisfies that the Gaussian distribution of the fracture image pixels is univariate. ${ }^{6}$ Then the probability model that all pixels of the fracture image frame form a normally distributed target and background can be expressed as

$$
p\left(x \mid w_{i}\right)=\frac{1}{\sqrt{2 \pi \sigma}} \exp \left(-\frac{1}{2}\left(\frac{x-\mu)}{\sigma}\right)^{2}\right)
$$

$p\left(x \mid w_{i}\right)$ is a univariate normal distribution. $w_{i}$ is the gray information feature value of the fracture image. In frame $K=2,3, \cdots, L$, if the mean and variance of the target and background of the fracture image are updated, it can be expressed as

$$
\begin{aligned}
& \mu_{K+1}=\frac{K-1}{K} \mu_{K}+\frac{1}{K} \mu_{K} \\
& \sigma_{K+1}^{2}=\frac{K-1}{K} \sigma_{K}^{2}+\frac{1}{K} \sigma_{K}^{2}
\end{aligned}
$$

In frame $K=L+1$, if the mean and variance of the target and background of the fracture image are updated, it can be expressed as

$$
\begin{aligned}
& \mu_{K+1}=(1-\rho) \mu_{K}^{\prime}+\rho \mu_{K+1} \\
& \sigma_{K+1}^{2^{\prime}}=(1-\rho) \sigma_{K}^{2^{\prime}}+\rho \sigma_{K}^{2}
\end{aligned}
$$

$\mu_{K}=\frac{1}{N_{K}} \sum_{j=1}^{N_{K}} I_{j}$ is the statistical mean value of the target and background points in the fracture image of the first $K$ frame. $\sigma_{K}^{2}=\frac{1}{N_{K}} \sum_{j=1}^{k}\left(I_{j}-\mu_{K}\right)^{2}$ is the variance of the target and background points in the fracture image of the first $K$ frame. $\mu_{K}$ is the mean value of the Gaussian model in the target and background sample points of the fracture map in the $K$ frame. $\sigma_{K}^{2}$ is the variance of the Gaussian model in the target and background sample points of the fracture map in the $K$ frame. $N_{K}$ is the number of sample points of the fracture image target and background. $I_{j}$ is the gray value of each sample point of the fracture image. $\rho$ is the update rate.

In order to quickly find the fracture image target in the nearby area centered on the original target position, we use Kalman filter to estimate the target position of the fracture image. ${ }^{7}$ Assign the target center position and action speed of the fracture image in the first frame to $X_{1}$, then the estimated fracture covariance can be expressed as

$$
\mu_{k+1}=M X_{k}
$$

$M$ is the structural parameter of the filter. $X_{K}$ is the estimated covariance value of the target center position of the fracture image and the motion speed in the $K$ image.

\section{RESULTS}

The positive evaluation criteria for BMP2 and TGF $\beta 1$ mRNA are dark blue particles in the cytoplasm. The first day after the fracture was the hematoma stage. There were no positive signals of BMP2 and TGF $\beta 1$ in the fractured end and surrounding tissue cells. On the third day after fracture, hematoma and fibrosis, undifferentiated mesenchymal cells scattered in the periosteum of the fractured end were BMP2 positive, but TGF $\beta 1$ basically had no positive signal. ${ }^{8}$ On the 5 th day, the callus 
was composed of granulation tissue, and the proliferated mesenchymal cells migrated and proliferated to the bone end. The mesenchymal cells gathered around some bone residues and fragments were BMP2 positive, and the number of positive cells in the periosteum increased. (Figure 1)

On the 7th day, intramembranous osteogenesis occurred, the fractured bone grew actively, the new bone trabecula increased significantly, and BMP2 positive signals were seen in the osteoblasts and undifferentiated mesenchymal cells around the new bone. (Figure 2)

Undifferentiated mesenchymal cells proliferated in the fractured end of the bone on the 5 th and 7 th days after fracture, and undifferentiated mesenchymal cells scattered in the periosteum of the fractured end and around the new bone trabecula. Among them, the osteoblasts were weakly positive for TGF $\beta 1$. (Figure 3)

On the 11th day after fracture, the intramembranous osteogenesis was active, and the new bone trabecula basically covered the bone stump. The number of cartilage islands increased, and BMP2 in osteoblasts and chondrocytes was positive, but it was weaker than before. (Figure 4)

The number of TGF $\beta 1$ positive cells increased, and the intensity of the positive signal was also significantly enhanced. Osteoblasts were positive for TGF $\beta 1$, and almost all chondrocytes in the cartilage islands around the bone stump were strongly positive for TGF $\beta 1$. (Figure 5)

On the 14th day after the fracture, the bone trabecula became thicker and formed a bone marrow cavity, showing more mature bone tissue. The intensity of BMP2 positive signal decreased, and the number of positive cells also decreased significantly. The TGF $\beta 1$ positive signal is still strong in osteoblasts and chondrocytes (Figure 6).

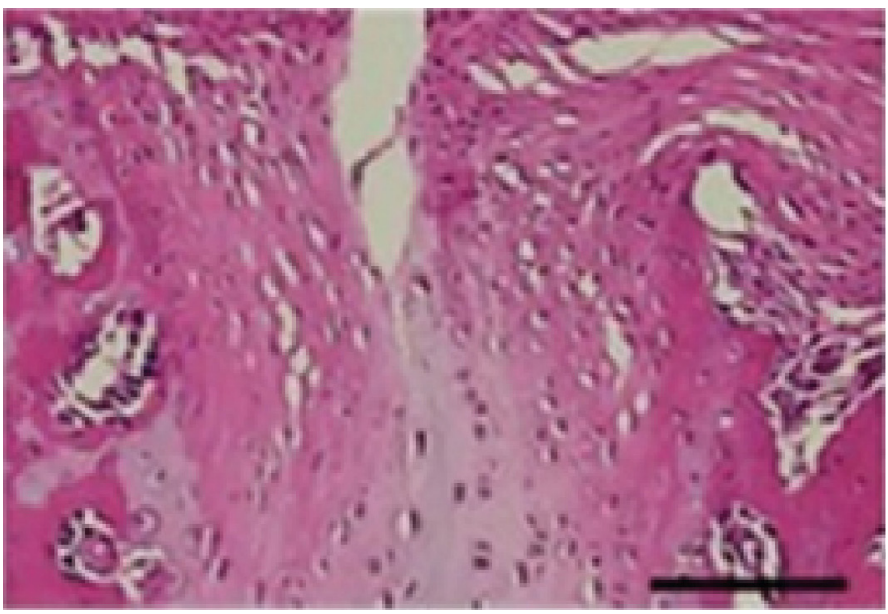

Figure 1. Undifferentiated mesenchymal cells in the periosteum are BMP2 positive on day 5 after fracture.

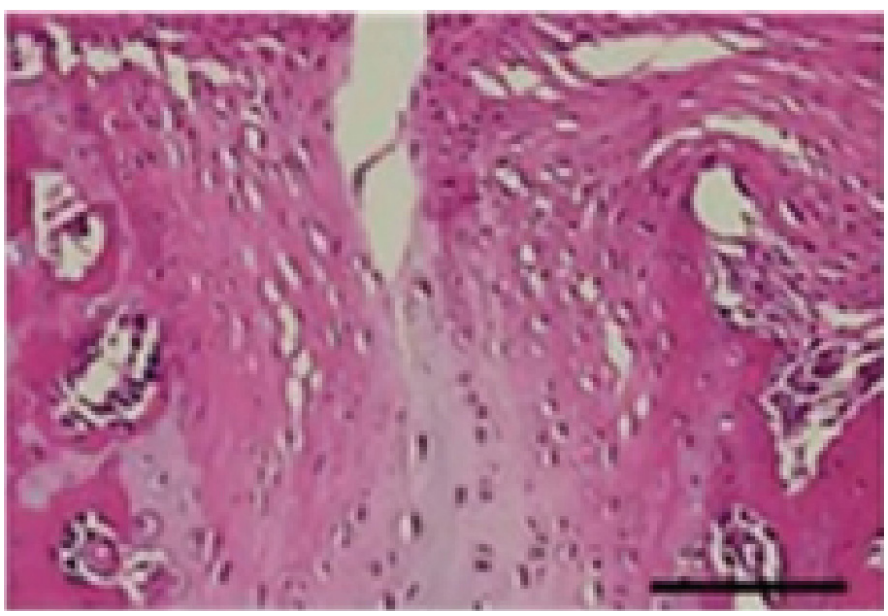

Figure 2. On the 7th day after the fracture, the osteoblasts around the new bone trabecula were BMP positive.

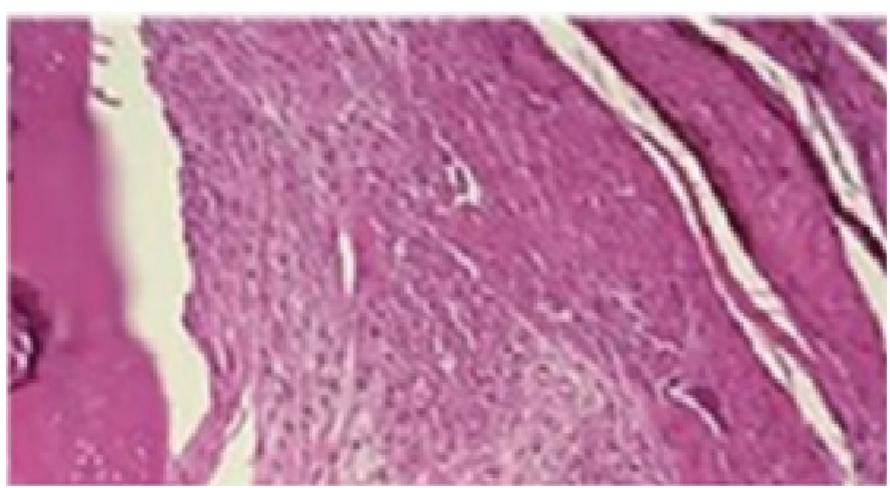

Figure 3. On the 7th day after the fracture, a positive signal of TGF $\beta 1$ is seen in the osteoblasts around the new bone trabecula.

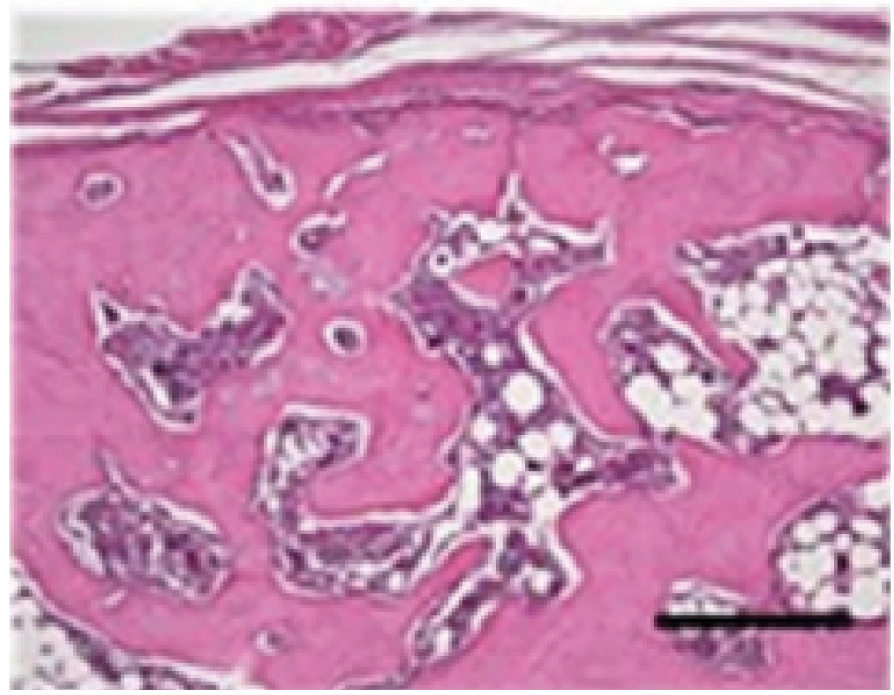

Figure 4. BMP2 positive signal is seen in chondrocytes on the 11th day after fracture, but it is weaker than before.

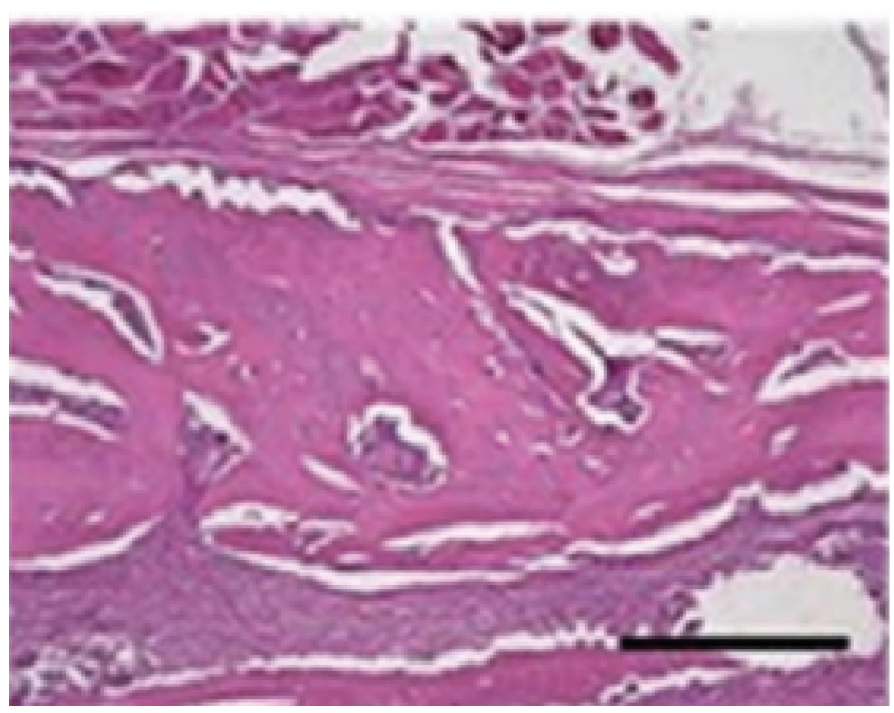

Figure 5. On the 11th day after fracture, the positive signal of TGF $\beta 1$ in chondrocytes increased.

On the 21 st to 28th day, the new bone at the fracture was connected into a piece, which tended to connect the broken end of the bone and seal the communication between the outside world and the bone marrow cavity. The number of TGF 31 and BMP2 positive cells was significantly reduced. In osteosarcoma, there are strong positive signals of BMP2 and TGF $\beta 1$ in tumorous chondrocytes. The blank control omitting the probe showed no positive signal. The positive signal was significantly weakened after RNAase digestion. 


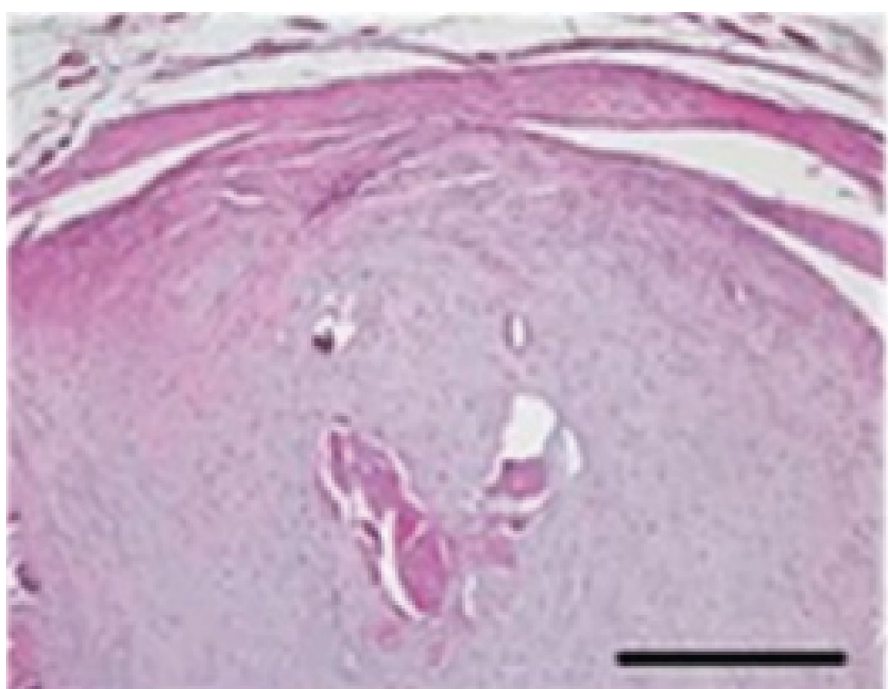

Figure 6. On the 14th day after the fracture, there is still a strong TGF $\beta 1$ positive signal.

\section{DISCUSSION}

Bone is a tissue with strong regeneration ability. Fracture healing can be divided into four stages in histology, namely the immediate post-injury reaction stage, the intramembranous bone formation stage, the cartilage formation stage and the cartilage ossification stage. Bone tissue defects are cured by the morphogenesis, cell differentiation and regeneration and repair of the tissue. ${ }^{9}$ The repair of bone tissue is different from other tissue repairs, not only in the potential of bone tissue to differentiate itself. What is important is that tissues other than bone can produce osteogenesis under the action of osteoinductive factors. The discovery of BMP provides a theoretical basis for explaining the occurrence, regeneration and repair of bone. A large number of studies have confirmed that undifferentiated mesenchymal cells around blood vessels can differentiate into cartilage and bone under the induction of endogenous or exogenous BMP. At present, it is believed that the center and key of fractures and bone defects is the activation of cells and the release of osteogenic signals, and BMP is the initial signal molecule that makes mesenchymal cells differentiate into bone cells. With the emergence of new cloning probes and high-sensitivity detection methods, we can understand the expression of regulatory factors in the process of fracture healing from the genetic level. The results of this experiment show that the gene expression level of BMP2 is higher in the intramembranous osteogenesis stage of the early fracture healing. Undifferentiated mesenchymal cells can synthesize BMP2mRNA. As the cells continue to differentiate and mature, the ability to synthesize BMP2mRNA gradually declines. The expression of BMP in fracture healing was observed by immunohistochemical method, and the positive rate was higher in the early undifferentiated mesenchymal cells. Because the expression of BMP in undifferentiated mesenchymal cells was detected from protein and gene levels. This suggests that undifferentiated mesenchymal cells in a differentiated state have the function of synthesizing and secreting BMP. BMP plays a role in the process of bone induction in the early stage of bone growth and healing, and plays an important role in tissue morphogenesis and cell differentiation.

Although BMP and TGF $\beta$ belong to the TGF $\beta$ superfamily, the biological effects of the two are not exactly the same. The most obvious difference is that TGF $\beta$ alone has no ectopic osteogenesis effect and no osteoinduction outside the bone tissue. However, local application of TGF $\beta$ can promote the formation of callus after fracture and increase the strength of the callus. It can promote the synthesis of collagen by osteoblasts and enhance the expression of type I collagen in the cells. TGF $\beta$ can accumulate differentiated osteoblasts and activate these cells under the synergistic effect of other factors. ${ }^{10}$ This accelerates bone repair and regeneration. The author found that TGF $\beta 1 \mathrm{mRNA}$ was not synthesized or synthesized very little in the early stage of fracture repair. In the chondrogenesis and cartilage ossification stage, osteoblasts and chondrocytes have higher levels of TGF 1 mRNA expression. Some scholars have observed the positive staining of TGF $\beta 1$ in osteoblasts and chondrocytes in the process of fracture healing using immunohistochemical methods. This suggests that these cells have the function of synthesizing and secreting TGF $\beta 1$, and play a role in the process of bone tissue maturation and reconstruction.

BMP2 plays an important role in early bone induction. TGF $\beta 1$ promotes bone formation and maturation. They promote fracture repair from both morphogenesis and regeneration. The coordination of the two can better induce the formation of new bone and make the bone tissue more mature after remodeling.

\section{CONCLUSION}

Undifferentiated mesenchymal cells with osteogenic potential in the fracture or bone defect area can synthesize and secrete BMP. These cells are induced by BMP to generate a large amount of new bone tissue. With the differentiation and maturity of the cells, osteoblasts and chondrocytes can synthesize TGF $\beta$ and promote their division and proliferation. At the same time, TGF $\beta$ can also promote the active function of the existing osteoblasts and bone grandmother cells, thereby enhancing the osteogenic ability. For example, the combined application of BMP and TGF $\beta$ in the treatment of fractures and bone defects will better promote fracture healing and bone defect repair.

\section{ACKNOWLEDGMENT}

This work was supported by Key scientific research projects of Guangdong Sports Bureau in 2018-2019, Project number: GDSS2018N122.

All authors declare no potential conflict of interest related to this article

AUTHORS' CONTRIBUTIONS: Each author made significant individual contributions to this manuscript. Wei Shen: writing and performing surgeries; XiaoJun Liang: data analysis and performing surgeries, article review, and intellectual concept of the article.

\section{REFERENCES}

1. De Boer EN, van der Wouden PE, Johansson LF, van Diemen CC, Haisma HJ. A next-generation sequencing method for gene doping detection that distinguishes low levels of plasmid DNA against a background of genomic DNA. Gene Therapy. 2019;26(7);338-46.

2. Cantelmo RA, da Silva AP, Mendes-Junior CT, Dorta DJ. Gene doping: Present and future. Eur J Sport Sci. 2020;20(8):1093-101. doi: 10.1080/17461391.2019.1695952.

3. AL-Dafrawi A, Abdullah MA, Zawawi M, Ismail Z. Performance-enhancing medicines in sports: legal discussion International Journal of Law, Government and Communication. 2019;4(17);48-60. doi: 10.35631/ijlgc.417005

4. Levi SR, Oh JK, de Carvalho JRL Jr, Mahajan VB, Tsang SH, Sparrow JR. Quantitative autofluorescence following gene therapy with voretigene neparvovec. JAMA Ophthalmol. 2020;138(8):919-921. doi: 10.1001/jamaophthalmol.2020.2018.

5. Campbell MH, McNamee MJ. Ethics, genetic technologies and equine sports: the prospect of regulation of a modified therapeutic use exemption policy. Sport, Ethics and Philosophy. 2021;15(2):227-50. doi: https://doi.org/10.1080/17511321.2020.1737204

6. Lloyd A, Piglowska N, Ciulla T, Pitluck S, Johnson S, Buessing M, et al. Estimation of impact of RPE65 -mediated inherited retinal disease on quality of life and the potential benefits of gene therapy. $\mathrm{B}$ J Ophthalmol. 2019;103(11):1610-4. doi: 10.1136/bjophthalmol-2018-313089

7. Dehghani B, Rodeo S. Cell therapy-a basic science primer for the sports medicine clinician. Curr Rev Musculoskelet Med. 2019;12(4):436-45. doi: 10.1007/s12178-019-09578-y.

8. Venkatesan JK, Rey-Rico A, Cucchiarini M. Current trends in viral gene therapy for human orthopaedic regenerative medicine. Tissue Eng Regen Med. 2019;16(4);345-55.

9. Cheung HW, Wong KS, Lin VY, Wan TS, Ho EN. A duplex qPCR assay for human erythropoietin (EPO) transgene to control gene doping in horses. Drug Test Anal. 2021;13(1):113-21. doi: 10.1002/dta.2907

10. Rubin R. Gene Therapy for Sickle Cell Disease Shows Promise. JAMA. 2019 Jan 29;321(4):334. doi 10.1001/jama.2018.21119. 